\title{
Control of Exhaust Emissions from Copper Coated Gasohol Run Two Stroke Spark Ignition Engine with Catalytic Converter
}

\author{
M. V. S. Murali Krishna (Corresponding author) \\ Department of Mechanical Engineering \\ Chaitanya Bharathi Institute of Technology, Gandipet, Hyderabad-500075, India \\ Tel: 91-988-551-7936 E-mail: maddalivs@gmail.com \\ P. V. K. Murthy \\ Vivekananda Institute of Science and Information Technology \\ Shadnagar, Mahabubnagar-509216, India \\ Tel: 91-949-011-6544Ｅ-mail: Krishnamurthy_venkata@yahoo.co.in \\ S. Narasimha Kumar \\ Department of Mechanical Engineering \\ Chaitanya Bharathi Institute of Technology, Gandipet, Hyderabad-500075, India \\ Tel: 91-984-834-9240Ｅmail: snarsimhak@gmail.com \\ K. Kishor \\ Department of Mechanical Engineering \\ Chaitanya Bharathi Institute of Technology, Gandipet, Hyderabad-500075, India \\ Tel: 91-949-206-3710 E-mail: kkishormed@gmail.com
}

Received: September 5, $2011 \quad$ Accepted: September 18, $2011 \quad$ Published: December 31, 2011

doi:10.5539/mer.v1n1p24

URL: http://dx.doi.org/10.5539/mer.v1n1p24

\begin{abstract}
The major pollutants emitted from spark ignition (SI) engine are carbon mono oxide (CO) and un-burnt hydrocarbons (UBHC). If the engine is run with alcohol, aldehydes have to be checked also. These are hazardous and cause health problems to human beings but also have impact on environment. Hence control of these pollutants call for immediate attention. Copper of thickness 300 microns is coated over piston crown, and indie portion of cylinder liner and cylinder head of the spark ignition engine. Investigations have been carried out for controlling pollutants from two strokes, $2.2 \mathrm{~kW}$ brake power at the rated speed of $3000 \mathrm{rpm}$, copper coated spark ignition engine fitted with catalytic converter with different catalysts such as sponge iron and manganese ore run with gasohol (blend of $20 \%$ ethanol and $80 \%$ gasoline by volume). The influence of parameters of catalytic converter (such as void ratio, mass of catalyst, airflow rate, temperature of injected air) and parameters of engine (such as brake power and equivalence ratio) on these emissions are studied. A microprocessor-based analyzer is used for the measurement of CO/UBHC in the exhaust of the engine. Aldehydes are measured by DNPH (dinitrophenyl hydrazine) method. Catalytic parameters are found to show strong influence on reduction of the pollutants in the exhaust. Copper coated spark ignition engine (CCE) with gasohol operation reduced the exhaust emissions considerably when compared to conventional engine (CE) with pure gasoline operation.
\end{abstract}

Keywords: SI engine, Alternate fuel, Performance, Pollutants, Catalytic converter, Air injection

\section{Introduction}

Carbon Monoxide is major pollutant contributed by the automobile exhaust, particularly spark ignition engine, breathing of which causes many health disorders (Khopkar S M, 2011; Fulekar M H, 1999), like reduction of 
hemoglobin content in the blood, increases dizziness, breathing and respiratory problems, eye irritation, loss of appetite etc., It also causes (Sharma B K, 2008) detrimental effects on other animal and plant life besides, environmental disorders. This pollutant is considerably high during idling and peak load operation of the engine. Further, the carbon monoxide (CO) emissions in the exhaust of 2 and 4 stroke engines increase with the age of the vehicle (Usha Madhuri T, et al., 2004) and it depends on methodology of driving, road layout, traffic density etc. Hence Globally, stringent regulations are made for permissible CO levels in the exhaust of 2 and 4-stroke spark ignition engines. The formation of un-burnt hydrocarbon (UBHC) is due to incomplete combustion. The two important reasons for incomplete combustion of the fuel are cool metal surfaces of the combustion chamber and imperfect mixture ratio. Of many methods available for reduction of $\mathrm{CO} / \mathrm{UBHC}$ emissions, the one employing a catalytic converter (Murthy, P.V.K., et al., 2011) is more effective. The use of platinum group metals as catalysts is quite expensive and hence efforts are on for search of cheaper catalysts (Murthy, P.V.K., et al., 2011; Luo M F and Zheng X M., 1999; Murali Krishna, M.V.S., et al., 2005). Further modification of engine design (Nedunchezhian N and Dhandapani S., 2000; Murali Krishna M.V.S.,et al., 2010; Murali Krishna M.V.S., et al., 2011) and fuel composition (Al-Farayedhi, A. A., et al., 2004; Ceviz, M.A. and Yu ksel, F. 2005; Nakata, K., 2006; Pearson, R.J., 2007; Bahattin Celik M., 2008; Narasimha Kumar S., et al., 2011) are also found to be advantageous in controlling the pollutants in the exhaust of the engine. The use of catalysts to promote combustion is an old concept. More recently copper is coated over piston crown and inside of cylinder head wall (Nedunchezhian N and Dhandapani S., 2000; Murali Krishna M.V.S., et al., 2010; Murali Krishna M.V.S., et al., 2011) and it is reported that the catalyst improves the fuel economy and increased combustion stabilization. In the context of depletion of fossil fuels due to increase of fuel consumption, the search for alternate and renewable fuels has also become pertinent. Ethanol is found to be a better alternate fuel for spark ignition engine compared to methanol as its calorific value is higher than methanol. And also the properties of ethanol are very close to those of gasoline (Al-Farayedhi, A. A., et al., 2004). Alcohol-gasoline blends have been tried (Al-Farayedhi, A. A., et al., 2004; Ceviz, M.A. and Yu ksel, F. 2005; Nakata, K., 2006; Pearson, R.J., 2007; Bahattin Celik M., 2008; Narasimha Kumar S., et al., 2011) to use in conventional spark ignition engine by many researchers. In addition, no major modification in the engine is required if low quantities of ethanol are blended with gasoline in spark ignition engine. In the present study, the effect of various engine parameters on the control of $\mathrm{CO} / \mathrm{UBHC}$ is reported with different versions of the engine such as $\mathrm{CE}$ and CCE with catalytic converter with different catalysts such as sponge iron and manganese ore and gasohol (ethanol blended gasoline, $20 \% \mathrm{~V} / \mathrm{V}$ ) as fuel. The performance of the catalyst is compared one over the other.

\section{Materials and Methods}

The experimental set-up employed in the present study is shown in Fig.1. A two- stroke, single-cylinder, air-cooled, spark ignition engine of brake power $2.2 \mathrm{~kW}$ at rated speed of $3000 \mathrm{rpm}$ is used. The engine is coupled to an eddy current dynamometer for measuring its brake power. The compression ratio of the engine is $7.5: 1$. The diameter and stroke of the cylinder are $57 \mathrm{~mm}$ each. In the present investigations, in reducing $\mathrm{CO} / \mathrm{UBHC}$ emissions, the piston crown and inside surface of the cylinder liner and cylinder head are coated (Nedunchezhian N and Dhandapani S., 2000) with copper by plasma spraying. A bond coating of Ni-Co-Cr alloy is applied for a thickness of about 100 microns using a $80 \mathrm{~kW}$ METCO plasma spray gun. Over the bond coating copper $89.5 \%$, Aluminium $9.5 \%$ and iron $1.0 \%$ is coated for 300 microns thickness. The coating had very high bond strength and does not wear off even after 50 hrs of operation. A catalytic converter shown in Fig. 2 is fitted to the exhaust pipe of the engine. Provision is made to inject a definite quantity of air into the catalytic converter. The converter is filled with sponge iron/manganese ore as catalyst with varying void ratios (where void ratio is the ratio between the volume occupied by the catalyst to the volume of the catalytic chamber) ranging from 0.1 to $1 . \mathrm{CO} / \mathrm{UBHC}$ emissions in the exhaust of the engine are measured with Netel Chromatograph analyzer. Various sets of the exhaust gases are drawn at three different locations, 1) immediately after the exhaust valve of the engine, 2) after the catalytic converter, and 3) at the outlet after air injection into the catalytic converter. The quantity of air drawn from the compressor and injected into the converter is kept constant so that the backpressure does not increase and reverse flow not created in the converter. DNPH method (Kuta, Oishi Kiyohiko and Tanaka To Shiaki, 1980) is employed for measuring aldehydes in the experimentation. The exhaust of the engine is bubbled through 2,4 dinitrophenyl hydrazine (2,4 DNPH) solution. The hydrazones formed were extracted into chloroform and are analyzed by employing high performance liquid chromatography (HPLC) to find the percentage concentration of formaldehyde and acetaldehyde in the exhaust of the engine.

Experiments are carried out on different configurations of the engine like CE and CCE with different test fuels like pure gasoline and gasohol under different sets like set-A- without catalytic converter and without air 
injection, set-B- with catalytic converter and without air injection and set-C with catalytic converter and with air injection.

\section{Results}

The variation of $\mathrm{CO}$ emissions at the peak load operation of the different configurations of the engine with gasoline as fuel with void ratio of the catalytic converter with different operating conditions with different catalysts.

The variation of $\mathrm{CO}$ emissions at the peak load operation of the $\mathrm{CE}$ with gasoline as fuel with void ratio of the catalytic converter with different operating conditions with sponge iron as catalyst is shown in Fig. 3(a).

The variation of $\mathrm{CO}$ emissions at the peak load operation of the $\mathrm{CE}$ with gasoline as fuel with void ratio of the catalytic converter with different operating conditions with manganese ore as catalyst is shown in Fig. 3(b).

The variation of $\mathrm{CO}$ emissions at the peak load operation of the CCE with gasoline as fuel with void ratio of the catalytic converter with different operating conditions with sponge iron as catalyst is shown in Fig. 3(c).

The variation of $\mathrm{CO}$ emissions at the peak load operation of the CCE with gasoline as fuel with void ratio of the catalytic converter with different operating conditions with manganese ore as catalyst is shown in Fig. 3(d).

The variation of $\mathrm{CO}$ emissions at the peak load operation of the different configurations of the engine with gasoline as fuel with mass of catalyst with different operating conditions with different catalysts is shown in Fig.4.

The variation of $\mathrm{CO}$ emissions at the peak load operation of the $\mathrm{CE}$ with gasoline as fuel with mass of the sponge iron as catalyst is shown in Fig. 4(a).

The variation of $\mathrm{CO}$ emissions at the peak load operation of the $\mathrm{CE}$ with gasoline as fuel with mass of manganese ore as catalyst is shown in Fig. 4(b).

The variation of $\mathrm{CO}$ emissions at the peak load operation of the CCE with gasoline as fuel with mass of the sponge iron as catalyst is shown in Fig. 4(c).

The variation of $\mathrm{CO}$ emissions at the peak load operation of the CCE with gasoline as fuel with mass of the manganese ore as catalyst is shown in Fig. 4(d).

The variation of $\mathrm{CO}$ emissions with different test fuels with different configurations of peak load of the engine with amount of injected air with different catalysts with void ratio of 0.7 is shown in Fig. 5 .

The variation of $\mathrm{CO}$ emissions with different test fuels with different configurations of peak load of the engine with the amount of injected air with sponge iron as catalyst, with void ratio of 0.7 is shown in 5(a).

The variation of $\mathrm{CO}$ emissions with different test fuels with different configurations of peak load of the engine with amount of injected air with manganese ore as catalyst with void ratio of 0.7 is shown in Fig. 5(b).

The variation of $\mathrm{CO}$ emissions with different test fuels with different configurations of peak load of the engine with temperature of injected air with different catalysts with void ratio of 0.7 is shown in Fig. 6.

The variation of $\mathrm{CO}$ emissions with different test fuels with different configurations of peak load of the engine with temperature of injected air with sponge iron as catalyst with void ratio of 0.7 is shown in Fig. 6(a).

The variation of $\mathrm{CO}$ emissions with different test fuels with different configurations of peak load of the engine with temperature of injected air with manganese ore as catalyst with void ratio of 0.7 is shown in 6(b).

Fig. 7 shows the variation of $\mathrm{CO}$ emissions with brake mean effective pressure (BMEP) in different versions of the engine with both test fuels.

Fig. 8 shows the variation of $\mathrm{CO}$ emissions with equivalence ratio, $\phi$ in both configurations of the engine with both test fuels.

Fig. 9 shows the variation of UBHC emissions with BMEP in different versions of the engine with both test fuels.

Fig. 10 shows the variation of UBHC emissions with equivalence ratio, $\phi$ in both configurations of the engine with both test fuels.

Table-1 shows the data of $\mathrm{CO}$ emissions with different test fuels with different configurations of the engine at different operating conditions of the catalytic converter with different catalyst.

Table-2 shows the data of UBHC emissions with different test fuels with different configurations of the engine at different operating conditions of the catalytic converter with different catalyst. 
Table-3 shows the data of formaldehyde emissions with different test fuels with different configurations of the engine at different operating conditions of the catalytic converter with different catalyst.

Table-4 shows the data of acetaldehyde emissions with different test fuels with different configurations of the engine at different operating conditions of the catalytic converter with different catalyst.

\section{Discussion}

From the Fig. 3(a), it can be observed that the $\mathrm{CO}$ emissions reduced considerably with increasing void ratio for different sets. However, beyond the void ratio of $0.7, \mathrm{CO}$ reduction is less due to decrease of surface/volume ratio and increase of backpressure on the engine.

From the Fig. 3(b), it is evident that $\mathrm{CO}$ emissions reduced considerably at void ratio of 0.7 with manganese ore as catalyst. However, the reduction of $\mathrm{CO}$ emissions is less when compared with sponge iron as catalyst. Similar trends are observed with Fig. 3(c) and Fig. 3(d) with that of Fig. 3(a). The optimum void ratio is found to be 0.7 with different configurations of the engine with different catalysts. From the Fig. 4(a), it can be observed that the $\mathrm{CO}$ emissions reduced considerably with increasing mass of catalyst. The reduction of $\mathrm{CO}$ emissions is found to be greater at mass of $2 \mathrm{~kg}$ of sponge iron. Beyond $2 \mathrm{~kg}$ of mass of sponge iron there is not much reduction of CO emissions. Oxidation reaction is completed with optimum mass of the catalyst. Hence more than $2 \mathrm{~kg}$ mass of the catalyst, there is not much reduction of $\mathrm{CO}$ emissions. From the Fig. 4(b), it can also be observed that the $\mathrm{CO}$ emissions reduced considerably with increasing mass of catalyst. The reduction of $\mathrm{CO}$ emissions is found to be greater at mass of $2.5 \mathrm{~kg}$ of manganese ore. Beyond $2.5 \mathrm{~kg}$ of mass of manganese ore there is not much reduction of $\mathrm{CO}$ emissions. For the same volume of the catalyst (void ratio is the same), the mass of the manganese ore is more as its density is high when compared with sponge iron. The trends observed with CCE are similar to those of CE with both catalysts. Hence Fig. 4(c) and Fig. 4(d) follow the similar trends of Fig. 4(a) and Fig. 4(b). From the Fig. 5(a), it can be observed that percentages of $\mathrm{CO}$ emissions are found to be lower when injected air quantity is $60 \mathrm{l} / \mathrm{min}$ for $\mathrm{CE}$ and $50 \mathrm{l} / \mathrm{min}$ for CCE respectively with gasoline as fuel. However, with gasohol operation, $\mathrm{CO}$ reduction is found to be higher at $40 \mathrm{l} / \mathrm{min}$ on both versions of the engine. Excessive airflow rate has low residence time, while lower airflow rate is not sufficient for oxidation reaction to convert CO to carbon dioxide. Thus gasohol requires lower quantity of air in CCE when compared to pure gasoline operation on CE.

Fig. 5(b) follows the similar trend with Fig. 5(a) as same void ratio is maintained. From the Fig. 6(a), it can be observed that as temperature of injected air increased, $\mathrm{CO}$ emissions are observed to be low for both test fuels with different configurations of the engine. When temperature of the injected air is $120^{\circ} \mathrm{C}, \mathrm{CO}$ emissions are recorded at lower levels with gasoline operation on both versions of the engine, while it is $180^{\circ} \mathrm{C}$ with gasohol operation. This is due to lower exhaust gas temperature with gasohol operation, with which temperature needed to promote oxidation reaction is higher when compared to gasoline. Fig. 6(b) follows the similar trend of Fig. 6(a). However, the percentage reduction of $\mathrm{CO}$ is less with manganese ore when compared with sponge iron. Fig. 7 shows the variation of $\mathrm{CO}$ emissions with BMEP in different versions of the engine with both test fuels. Gasohol decreased CO emissions at all loads when compared to pure gasoline operation on CCE and CE, as fuel-cracking reactions (Khopkar S M, 2011) are eliminated with ethanol. Efficient combustion with gasohol coupled with catalytic activity with copper coating decreased $\mathrm{CO}$ emissions considerably with gasohol operation on CCE in comparison with pure gasoline operation on CE. The combustion of alcohol produces more water vapor than free carbon atoms as ethanol has lower $\mathrm{C} / \mathrm{H}$ ratio of 0.33 against 0.5 of gasoline. Ethanol has oxygen in its structure and hence its blends have lower stoichiometric air requirements compared to gasoline. Therefore more oxygen that is available for combustion with the blends of ethanol and gasoline, leads to reduction of CO emissions. Ethanol dissociates in the combustion chamber of the engine forming hydrogen, which helps the fuel-air mixture to burn quickly and thus increases combustion velocity, which brings about complete combustion of carbon present in the fuel to $\mathrm{CO}_{2}$ and also $\mathrm{CO}$ to $\mathrm{CO}_{2}$ thus makes leaner mixture more combustible, causing reduction of $\mathrm{CO}$ emissions. $\mathrm{CCE}$ reduces $\mathrm{CO}$ emissions in comparison with $\mathrm{CE}$. Copper or its alloys acts as catalyst in combustion chamber, whereby facilitates effective combustion of fuel leading to formation of $\mathrm{CO}_{2}$ instead of $\mathrm{CO}$. Similar trends are observed with Reference- 8 with pure gasoline operation on CCE. Fig. 8 shows the variation of $\mathrm{CO}$ emissions with equivalence ratio, $\phi$ in both configurations of the engine with both test fuels. At leaner mixtures marginal increase in $\mathrm{CO}$ emissions, and at rich mixtures drastic increase in $\mathrm{CO}$ emissions are observed with both test fuels in different configurations of the engine. With gasohol operations minimum $\mathrm{CO}$ emissions are observed at $\phi=0.85$ and with pure gasoline operations minimum $\mathrm{CO}$ emissions are observed at $\phi=0.9$ with both configurations of the engine. This is due to lower value of stoichiometric air requirement of gasohol when compared with gasoline. Very rich mixtures have incomplete combustion. Some carbon only burns to $\mathrm{CO}$ and not to $\mathrm{CO}_{2}$. Fig. 9 shows the variation of un-burnt hydro carbon emissions (UBHC) with BMEP in different versions of the engine with both test fuels. UBHC 
emissions followed the same trend as CO emissions in CCE and CE with both test fuels, due to increase of flame speed with catalytic activity and reduction of quenching effect with CCE. Catalytic converter reduced pollutants considerably with $\mathrm{CE}$ and $\mathrm{CCE}$ and air injection into catalytic converter further reduced pollutants. In presence of catalyst, pollutants get further oxidised to give less harmful emissions like $\mathrm{CO}_{2}$. Sponge iron decreased $\mathrm{CO}$ emissions considerably when compared with manganese ore in both versions of the engine with different configurations of the engine. Similar trends are observed with Reference- 8 with pure gasoline operation on CCE. Fig. 10 shows the variation of UBHC emissions with equivalence ratio, $\phi$ with both test fuels in both configurations of the engine. The trends followed by UBHC emissions are similar to those of CO emissions. Drastic increase of UBHC emissions is observed at rich mixtures with both test duels in different configurations of the engine. In the rich mixture some of the fuel will not get oxygen and will be completely wasted. During starting from the cold, rich mixture is supplied to the engine, hence marginal increase of UBHC emissions is observed at lower value of equivalence ratio. From the Table-1 and Table-2, it can be observed that $\mathrm{CO}$ and UBHC emissions deceased considerably with catalytic operation in set-B with gasohol and further decrease in emissions is more pronounced with air injection with the same fuel. The effective combustion of the gasohol itself decreased CO emissions in both configurations of the engine. Sponge iron decreased CO emissions effectively when compared with the manganese ore in both versions of the engine with both test fuels From Table-3 it can be observed that formaldehyde emissions increased drastically with gasohol operation in both versions of the engine in comparison with pure gasoline operation. However, the percentage increase in formaldehyde emissions is less with CCE when compared with CE. This shows that CCE decreases formaldehyde emissions considerably. With the both test fuels, CCE drastically decreased formaldehyde emissions in comparison with CE. The intermediate compounds will not be formed is the reason for decrease of formaldehyde emissions in CCE. This shows combustion is improved with catalytic activity in CCE which decreased formaldehyde emissions. Formaldehyde emissions decreased with Set-B operation and further decreased in Set-C operation in both versions of the engine with both test fuels. This is due to increase of oxidation reaction with the use of catalyst and air which caused reduction of formaldehyde contents. Set-B operation with catalytic converter decreased pollutants considerably with both test fuels with different configuration of the engine, while further decrease in pollutants is pronounced with Set-C operation. This is due to improved oxidation reaction of the catalyst and air. Sponge iron is more effective in reducing formaldehyde emissions, when compared with manganese ore. Table-4 follows the similar trend with Table-3. However, the magnitude of acetaldehyde concentration is higher in comparison with formaldehyde emissions in both versions of the engine with both test fuels.

\section{Conclusions}

A void ratio of 0.7 is found to be the optimum for different test fuels with different versions of the engine. $\mathrm{CO} / \mathrm{UBHC}$ emissions at peak load decreased by $20 \%-45 \%$ with the change of the engine configuration from conventional version to catalytic coated engine with test fuels. Pollutants decreased by $25-45 \%$ with the change of fuel from gasoline to gasohol in both versions of the engine under different operating conditions of the catalytic converter. Air injection decreased the emissions by $60 \%$ with different test fuels with different configurations of the engine. Increasing of temperature of air decreased $\mathrm{CO}$ emissions considerably. Lean mixtures decreased $\mathrm{CO}$ and UBHC emissions. At nearly $80 \%$ of the full load of the engine these pollutants decreased drastically.

\section{Acknowledgements}

The authors are thankful to the authorities of Chaitanya Bharathi Institute of Technology, Hyderabad for the facilities provided. The financial assistance provided by Andhra Pradesh Council of Science and Technology (APCOST) for this project is greatly acknowledged.

\section{References}

Al-Farayedhi, A. A., Al-Dawood, A. M., \& Gandhidasan, P. (2004). Experimental investigation of spark ignition engine performance using oxygenated fuel. ASME Journal of Engineering for Gas Turbines and Power, Vol. 126, 178-191. http://dx.doi.org/10.1115/1.1615254

Bahattin Celik, M. (2008). Experimental determination of suitable ethanol-gasoline blend rate at high compression ratio for gasoline engine. Applied Thermal Engineering, Vol. 28, 396-404. http://dx.doi.org/10.1016/j.applthermaleng.2007.10.028

Ceviz, M.A., \& Yu ksel, F. (2005). Effects of ethanol-unleaded gasoline blends on cyclic variability and emissions In a spark ignition engine. Applied Thermal Engineering, Vol. 25, 917-925. http://dx.doi.org/10.1016/j.applthermaleng.2004.07.019 
Fulekar M H. (1999). Chemical pollution - a threat to human life. Indian Journal of Environmental. Proection, 1(3), 353-359.

Inove To Kuta, Oishi Kiyohiko, \& Tanaka To Shiaki, Toyota Japan. (1980). Determination of aldehydes in the automobile exhaust by HPL, Toyota Automobile Company, Technical Improvement Division, 21(4), 500-506.

Khopkar S M. (2011). Environmental Pollution Analysis. New Delhi, New Age International (P) Ltd, Publishers.

Luo M F, \& Zheng X M. (1999). CO oxidation activity and TPR characteristics of $\mathrm{CeO}_{2}$-supported manganese oxide catalyst. Indian Journal of. Chemistry. 38, 703-707.

Murali Krishna, M. V. S., Kishor, K., Gupta, A. V. S. S. K. S., Narasimha Kumar., S., \& Reddy, D.N. (2010). Control of pollutants from copper coated spark ignition engine with gasohol with catalytic converter. Pollution Research, Vol. 29, No. 3, 391-395.

Murali Krishna, M.V.S., Narasimha Kumar, S., \& Krishna Murthy, P.V. (2011). Control of aldehyde emissions from copper coated spark ignition engine fueled with alcohol blended gasoline. International Journal of Engineering Research and Applications (IJERA), ISSN: 2248-9622, Vol. 1, Issue 2, 337-340.

Murali Krishna, M. V. S., Prasad, P. R. K., Ajay Kumar, M., Narayana, M. V., \& Balu, B. (2005). Parametric studies of catalytic converter on reduction of carbon monoxide in spark ignition engine with gasohol. Engineering Today, Vol. V11, No. 6, June, 3-7.

Murthy, P.V.K., Murali Krishna, M.V.S., Narasimha Kumar, S., Kishor, K., \& P. Giridhar Reddy. (2011). Performance of copper coated two stroke spark ignition engine with alternate fuels with catalytic converter. International Journal of Engineering \& Techno-science, Vol. 2, No. 2, 145-149.

Nakata, K. (2006). The effect of ethanol fuel on a spark ignition engine. SAE Paper No-2006-01-3380.

Narasimha Kumar, S., Kishor, K., Murali Krishna., M.V.S. and P.V.K. Murthy. (2011). Studies on exhaust emissions from copper coated gasohol run spark ignition engine with catalytic converter. International Scholarly Research Net Work (ISRN) in Mechanical Engineering (ME). Vol. 2, Article 757019, 1-6.

Nedunchezhian N, \& Dhandapani S. (2000). Experimental investigation of cyclic variation of combustion parameters in a catalytically activated two-stroke SI engine combustion chamber, Engineering Today, 2, 11-18.

Pearson, R. J. (2007). Alcohol based fuels in high performance engines. SAE Paper No - 2007-01-0056.

Sharma B K. (2008). Engineering Chemistry, Meerut, Pragathi Prakashan (P) Ltd.

Usha Madhuri T, Srinivas T, \& Ramakrishna K. (2004). A study on automobile exhaust pollution with regard to carbon monoxide emissions. Nature, Env. \& Poll. Tech, 2(4), 473-474.

Table 1. Data of 'CO' emissions (\%) with different test fuels with different configurations of the engine at different operating conditions of the catalytic converter with different catalysts

\begin{tabular}{|c|c|c|c|c|c|c|c|c|}
\hline \multirow{4}{*}{ Set } & \multicolumn{4}{|c|}{ Conventional Engine (CE) } & \multicolumn{3}{c|}{ Copper Coated Engine (CCE) } \\
\cline { 2 - 9 } & \multicolumn{2}{|c|}{ Pure Gasoline } & \multicolumn{2}{c|}{ Gasohol } & \multicolumn{2}{c|}{ Pure Gasoline } & \multicolumn{2}{c|}{ Gasohol } \\
\cline { 2 - 9 } & $\begin{array}{c}\text { Sponge } \\
\text { iron }\end{array}$ & $\begin{array}{c}\text { Manganese } \\
\text { ore }\end{array}$ & $\begin{array}{c}\text { Sponge } \\
\text { iron }\end{array}$ & $\begin{array}{c}\text { Manganese } \\
\text { ore }\end{array}$ & $\begin{array}{c}\text { Sponge } \\
\text { iron }\end{array}$ & $\begin{array}{c}\text { Manganese } \\
\text { ore }\end{array}$ & $\begin{array}{c}\text { Sponge } \\
\text { iron }\end{array}$ & $\begin{array}{c}\text { Mangan } \\
\text { ese ore }\end{array}$ \\
\hline Set-A & 5.0 & 5.0 & 3.5 & 3.5 & 4.0 & 4.0 & 2.9 & 2.9 \\
\hline Set-B & 3.0 & 4.0 & 2.3 & 2.8 & 2.4 & 3.2 & 1.9 & 2.32 \\
\hline Set-C & 2.0 & 3.0 & 1.5 & 2.1 & 1.6 & 2.4 & 1.26 & 1.74 \\
\hline
\end{tabular}

Set-A- Without catalyst, Set-B- With catalyst, Set-C- With catalyst and with air injection. 
Table 2. Data of 'UBHC' emissions (ppm) with different test fuels with different configurations of the engine at different operating conditions of the catalytic converter with different catalysts

\begin{tabular}{|c|c|c|c|c|c|c|c|c|}
\hline \multirow{3}{*}{ Set } & \multicolumn{4}{|c|}{ Conventional Engine (CE) } & \multicolumn{4}{c|}{ Copper Coated Engine (CCE) } \\
\cline { 2 - 10 } & \multicolumn{2}{|c|}{ Pure Gasoline } & \multicolumn{2}{c|}{ Gasohol } & \multicolumn{2}{c|}{ Pure Gasoline } & \multicolumn{3}{c|}{ Gasohol } \\
\cline { 2 - 10 } & $\begin{array}{c}\text { Sponge } \\
\text { iron }\end{array}$ & $\begin{array}{c}\text { Manganese } \\
\text { ore }\end{array}$ & $\begin{array}{c}\text { Sponge } \\
\text { iron }\end{array}$ & $\begin{array}{c}\text { Manganese } \\
\text { ore }\end{array}$ & $\begin{array}{c}\text { Sponge } \\
\text { iron }\end{array}$ & $\begin{array}{c}\text { Manganese } \\
\text { ore }\end{array}$ & $\begin{array}{c}\text { Sponge } \\
\text { iron }\end{array}$ & $\begin{array}{c}\text { Manganese } \\
\text { ore }\end{array}$ \\
\hline Set-A & 750 & 750 & 562 & 562 & 600 & 600 & 450 & 450 \\
\hline Set-B & 450 & 600 & 340 & 450 & 360 & 480 & 270 & 360 \\
\hline Set-C & 300 & 450 & 225 & 330 & 240 & 360 & 180 & 270 \\
\hline
\end{tabular}

Set-A- Without catalyst, Set-B- With catalyst, Set-C- With catalyst and with air injection.

Table 3. Data of FORMALDEHYDE emissions (\% concentrations) in two-stroke SI engine with different test fuels with different configurations of the engine at different operating conditions of the catalytic converter with different catalysts

\begin{tabular}{|c|c|c|c|c|c|c|c|c|}
\hline \multirow{2}{*}{ Set } & \multicolumn{4}{|c|}{ Conventional Engine (CE) } & \multicolumn{4}{c|}{ Copper Coated Engine (CCE) } \\
\cline { 2 - 10 } & \multicolumn{2}{|c|}{ Pure Gasoline } & \multicolumn{2}{c|}{ Gasohol } & \multicolumn{2}{c|}{ Pure Gasoline } & \multicolumn{3}{c|}{ Gasohol } \\
\cline { 2 - 10 } & $\begin{array}{c}\text { Sponge } \\
\text { iron }\end{array}$ & $\begin{array}{c}\text { Manganese } \\
\text { ore }\end{array}$ & $\begin{array}{c}\text { Sponge } \\
\text { iron }\end{array}$ & $\begin{array}{c}\text { Manganese } \\
\text { ore }\end{array}$ & $\begin{array}{c}\text { Sponge } \\
\text { iron }\end{array}$ & $\begin{array}{c}\text { Manganese } \\
\text { ore }\end{array}$ & $\begin{array}{c}\text { Sponge } \\
\text { iron }\end{array}$ & $\begin{array}{c}\text { Manganese } \\
\text { ore }\end{array}$ \\
\hline Set-A & 9.1 & 11.1 & 14.6 & 16.5 & 6.8 & 8.6 & 9.3 & 11.2 \\
\hline Set-B & 6.3 & 8.2 & 7.0 & 9.2 & 4.1 & 6.1 & 5.0 & 7.1 \\
\hline Set-C & 3.5 & 5.4 & 5.9 & 7.7 & 3.2 & 5.1 & 3.9 & 5.8 \\
\hline
\end{tabular}

Table 4. Data of ACETALDEHYDE emissions (\% concentrations) in two-stroke SI engine with different test fuels with different configurations of the engine at different operating conditions of the catalytic converter with different catalysts

\begin{tabular}{|c|c|c|c|c|c|c|c|c|}
\hline \multirow{3}{*}{ Set } & \multicolumn{4}{|c|}{ Conventional Engine (CE) } & \multicolumn{4}{c|}{ Copper Coated Engine (CCE) } \\
\cline { 2 - 10 } & \multicolumn{2}{|c|}{ Pure Gasoline } & \multicolumn{2}{c|}{ Gasohol } & \multicolumn{2}{c|}{ Pure Gasoline } & \multicolumn{2}{c|}{ Gasohol } \\
\cline { 2 - 10 } & $\begin{array}{c}\text { Sponge } \\
\text { iron }\end{array}$ & $\begin{array}{c}\text { Manganese } \\
\text { ore }\end{array}$ & $\begin{array}{c}\text { Sponge } \\
\text { iron }\end{array}$ & $\begin{array}{c}\text { Manganese } \\
\text { ore }\end{array}$ & $\begin{array}{c}\text { Sponge } \\
\text { iron }\end{array}$ & $\begin{array}{c}\text { Manganese } \\
\text { ore }\end{array}$ & $\begin{array}{c}\text { Sponge } \\
\text { iron }\end{array}$ & $\begin{array}{c}\text { Manganese } \\
\text { ore }\end{array}$ \\
\hline Set-A & 7.7 & 9.6 & 16.8 & 18.7 & 4.9 & 6.8 & 12.6 & 14.5 \\
\hline Set-B & 4.9 & 6.8 & 8.4 & 10.5 & 3.5 & 5.5 & 7.5 & 9.3 \\
\hline Set-C & 2.1 & 4.0 & 7.0 & 9.1 & 1.4 & 3.3 & 5.2 & 7.2 \\
\hline
\end{tabular}




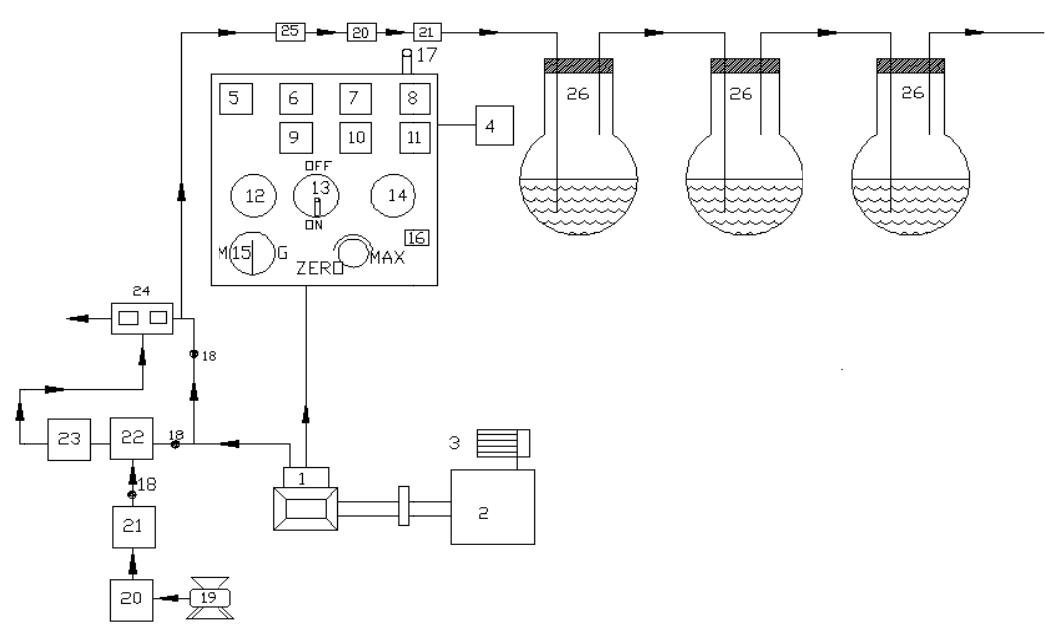

1. Engine, 2. Electrical swinging field dynamometer, 3. Loading arrangement, 4. Fuel tank, 5. Torque indicator/controller sensor, 6. Fuel rate indicator sensor, 7. Hot wire gas flow indicator, 8. Multi channel temperature indicator, 9. Speed indicator, 10. Air flow indicator, 11. Exhaust gas temperature indicator, 12. Mains ON, 13. Engine ON/OFF switch, 14. Mains OFF, 15. Motor/Generator option switch, 16. Heater controller, 17. Speed indicator, 18. Directional valve, 19. Air compressor, 20. Rotometer, 21. Heater, 22. Air chamber, 23. Catalytic chamber, 24. CO/HC analyzer, 25. Filter, 26. Round bottom flasks containing DNPH solution.

Figure 1. Schematic diagram of the experimental set-up

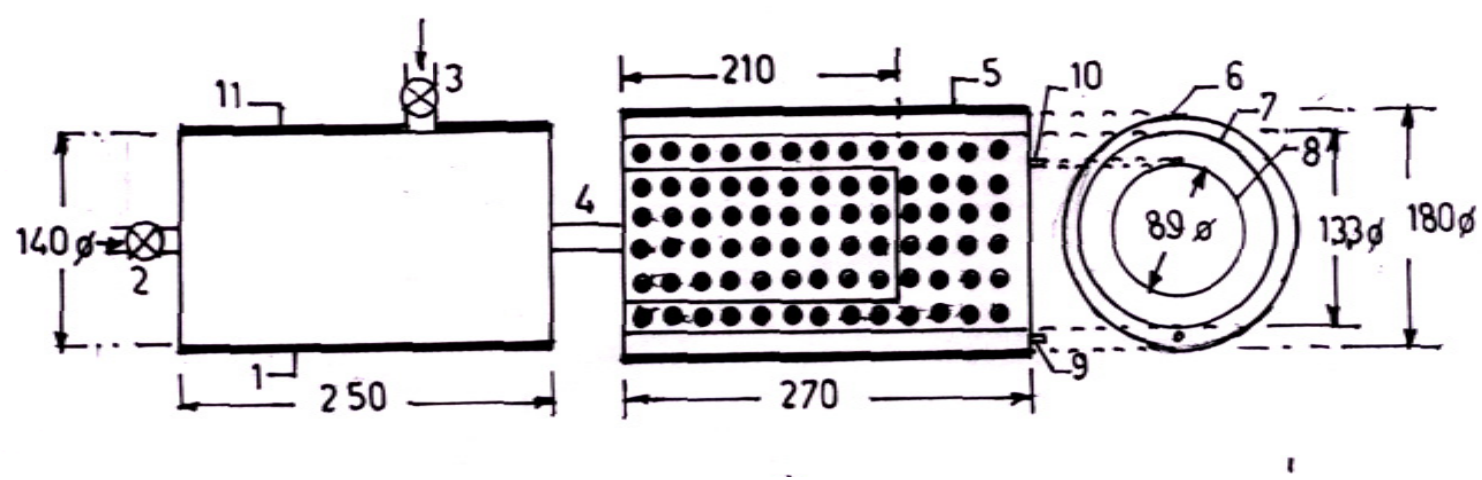

All dimensions are in $\mathrm{mm}$

1. Air chamber, 2. Inlet for air chamber from the engine, 3. Inlet for air chamber from the compressor, 4. Outlet for air chamber, 5. Catalytic chamber, 6. Outer cylinder 7. Intermediate-cylinder, 8. Inner-cylinder, 9. Outlet for exhaust gases, 10. Provision to deposit the catalyst and 11. Insulation.

Figure 2. Details of catalytic converter 


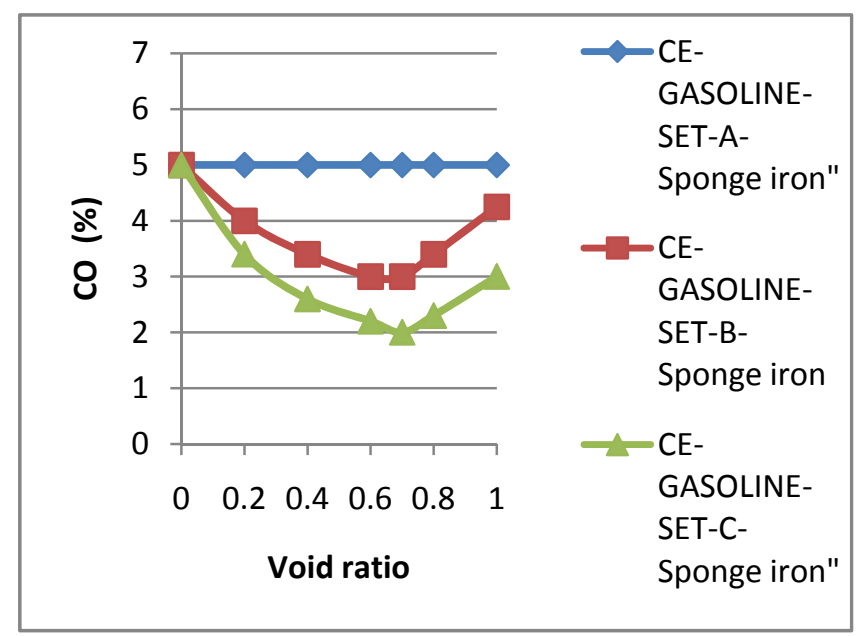

Figure 3(a). The variation of $\mathrm{CO}$ emissions at the peak load operation of the $\mathrm{CE}$ with gasoline as fuel with void ratio of the catalytic converter with different operating conditions with sponge iron

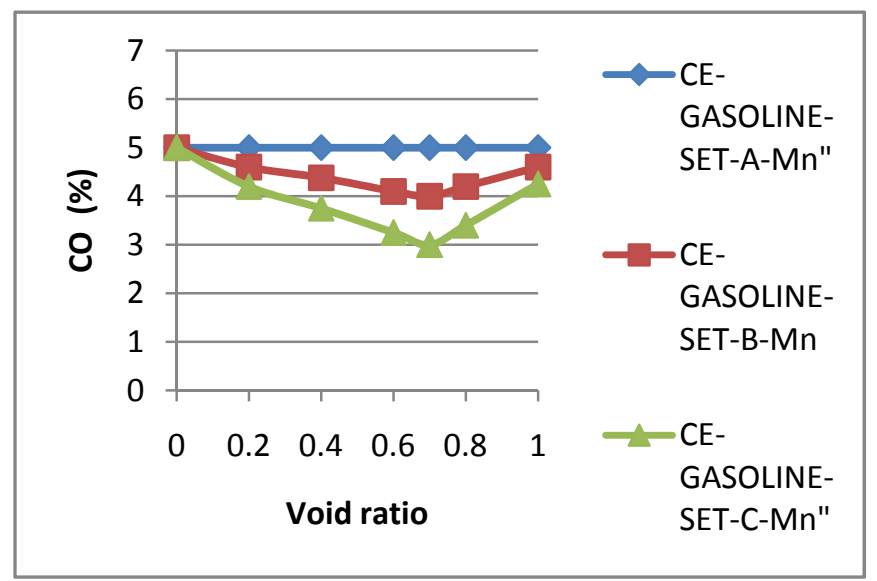

Figure 3(b). The variation of CO emissions at the peak load operation of the CE with gasoline as fuel with void ratio of the catalytic converter with different operating conditions with manganese ore as catalyst

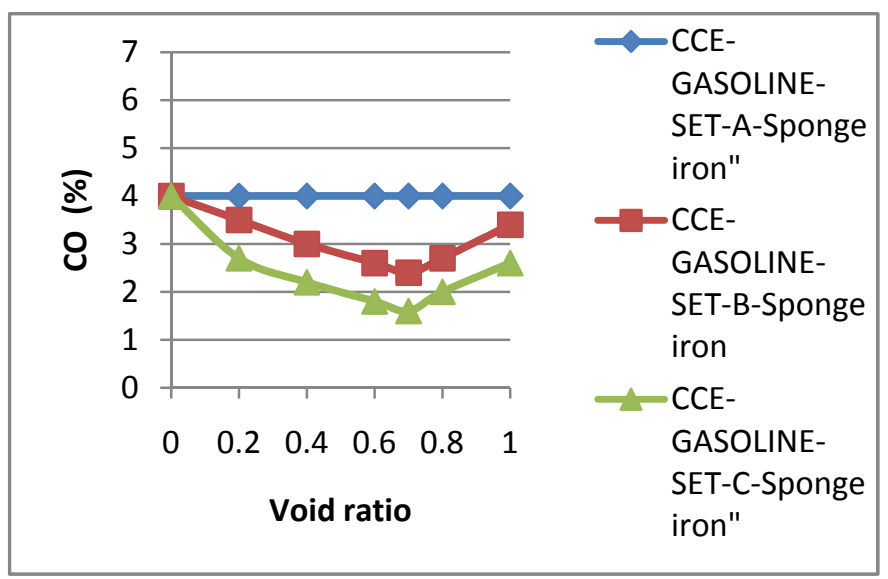

Figure 3(c). The variation of CO emissions at the peak load operation of the CCE with gasoline as fuel with void ratio of the catalytic converter with different operating conditions with sponge iron as catalyst 


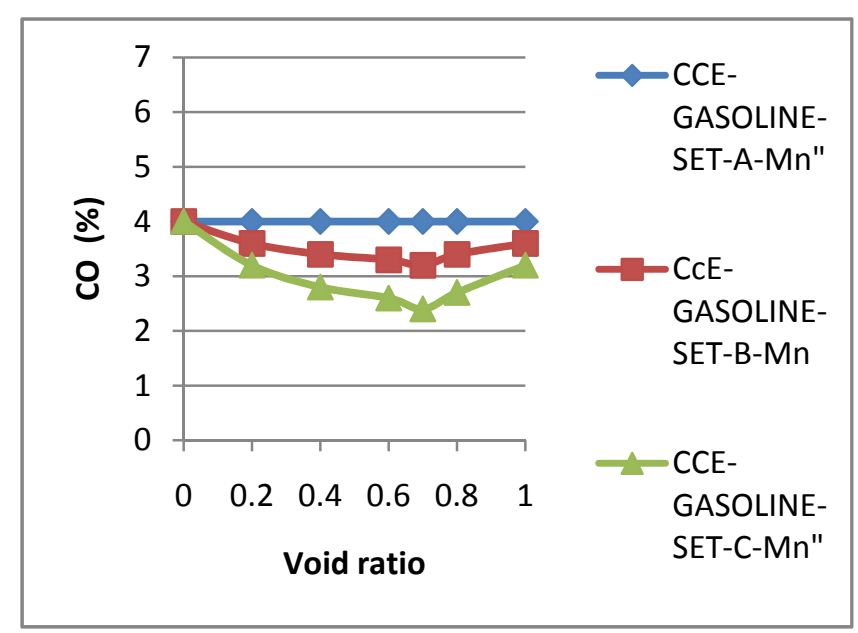

Figure 3(d). The variation of $\mathrm{CO}$ emissions at the peak load operation of the CCE with gasoline as fuel with void ratio of the catalytic converter with different operating conditions with manganese ore as catalyst

Figure 3. The variation of $\mathrm{CO}$ emissions at the peak load operation of the different versions of the engine with gasoline as fuel with void ratio of the catalytic converter with different operating conditions with different catalysts

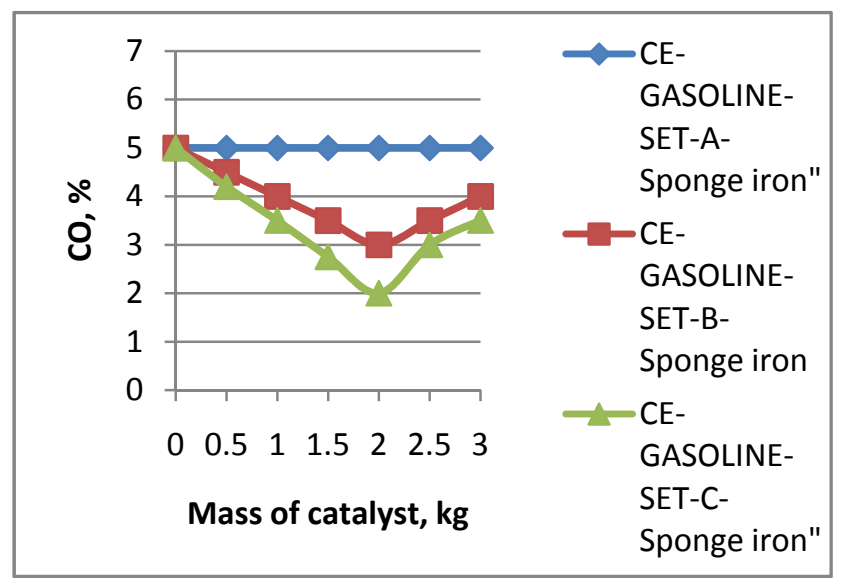

Figure 4(a). The variation of $\mathrm{CO}$ emissions at the peak load operation of the CE with gasoline as fuel with mass of the sponge iron as catalyst

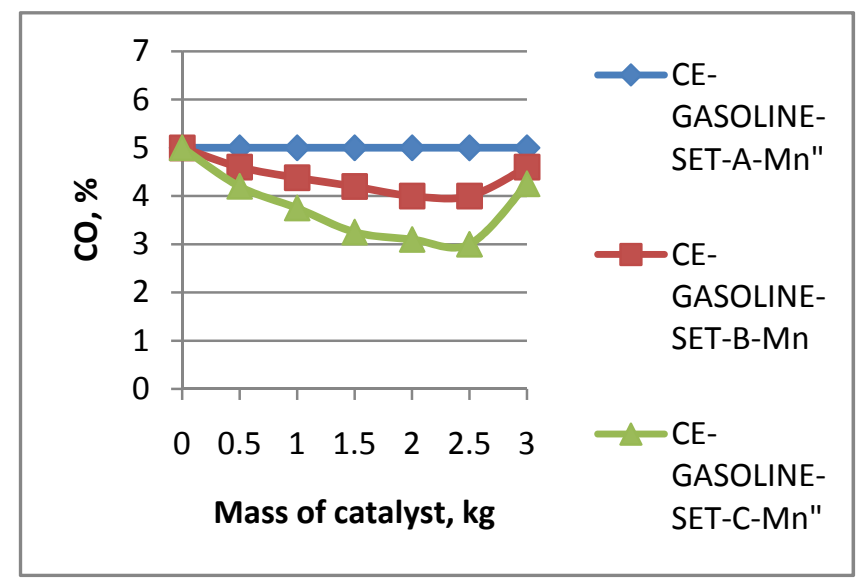

Figure 4(b). The variation of $\mathrm{CO}$ emissions at the peak load operation of the $\mathrm{CE}$ with gasoline as fuel with mass of the manganese ore as catalyst 


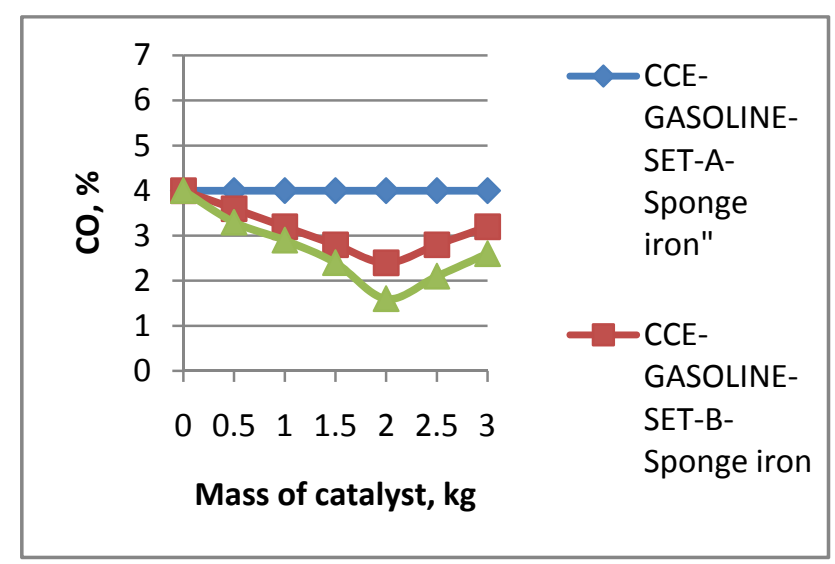

Figure 4(c). The variation of CO emissions at the peak load operation of the CCE with gasoline as fuel with mass of the sponge iron as catalyst

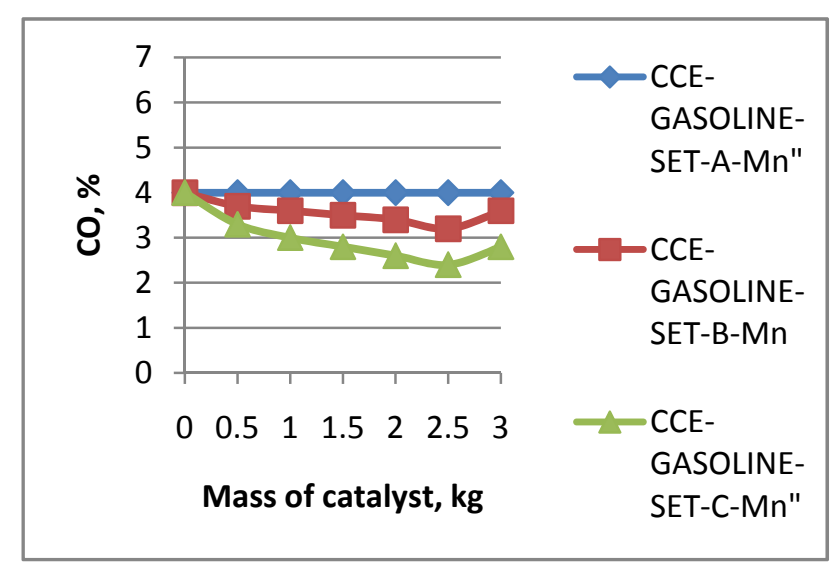

Figure 4(d). The variation of CO emissions at the peak load operation of the CCE with gasoline as fuel with mass of the manganese ore as catalyst

Figure 4. The variation of $\mathrm{CO}$ emissions at the peak load operation of the different versions of the engine with gasoline as fuel with mass of the different catalysts

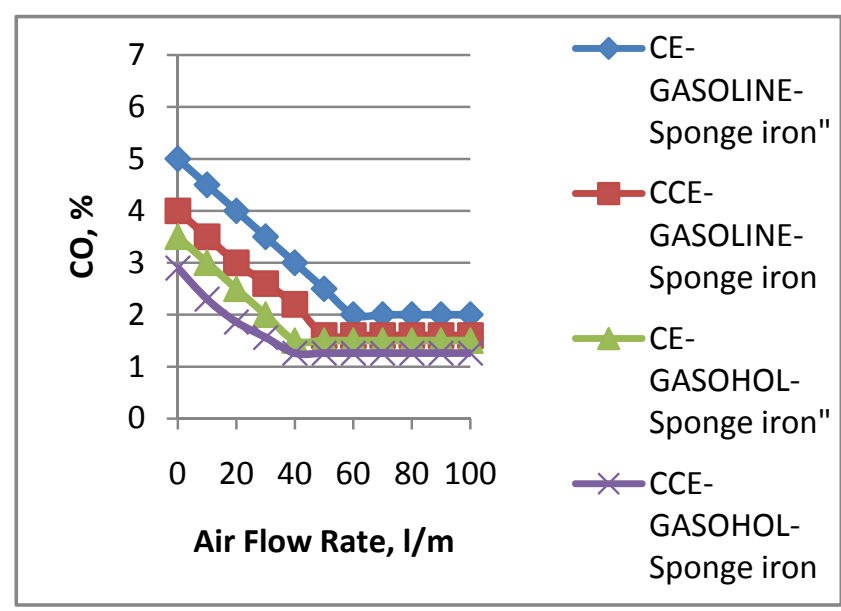

Figure 5(a). The variation of $\mathrm{CO}$ emissions with different test fuels with different configurations of peak load of the engine with the amount of injected air with sponge iron as catalyst, with void ratio of 0.7 


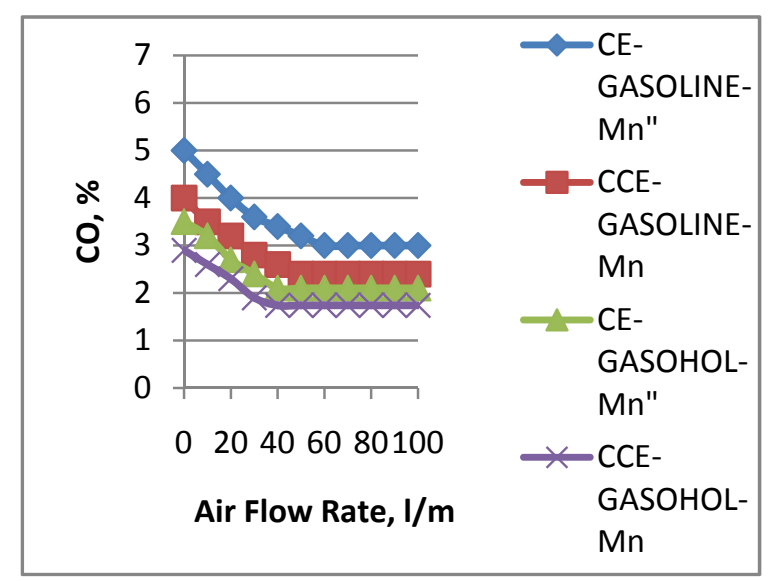

Figure 5(b). The variation of $\mathrm{CO}$ emissions with different test fuels with different configurations of peak load of the engine with amount of injected air with manganese ore as catalyst with void ratio of 0.7

Figure 5. The variation of $\mathrm{CO}$ emissions with different test fuels with different configurations of peak load of the engine with amount of injected air with different catalysts with void ratio of 0.7

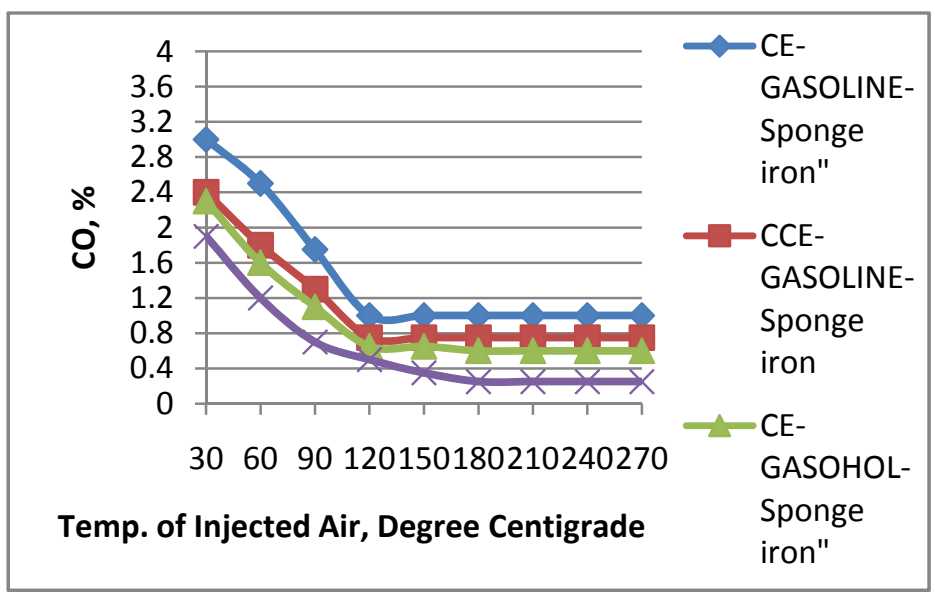

Figure 6(a). The variation of $\mathrm{CO}$ emissions with different test fuels with different configurations of peak load of the engine with temperature of injected air with sponge iron with void ratio of 0.7 as catalyst

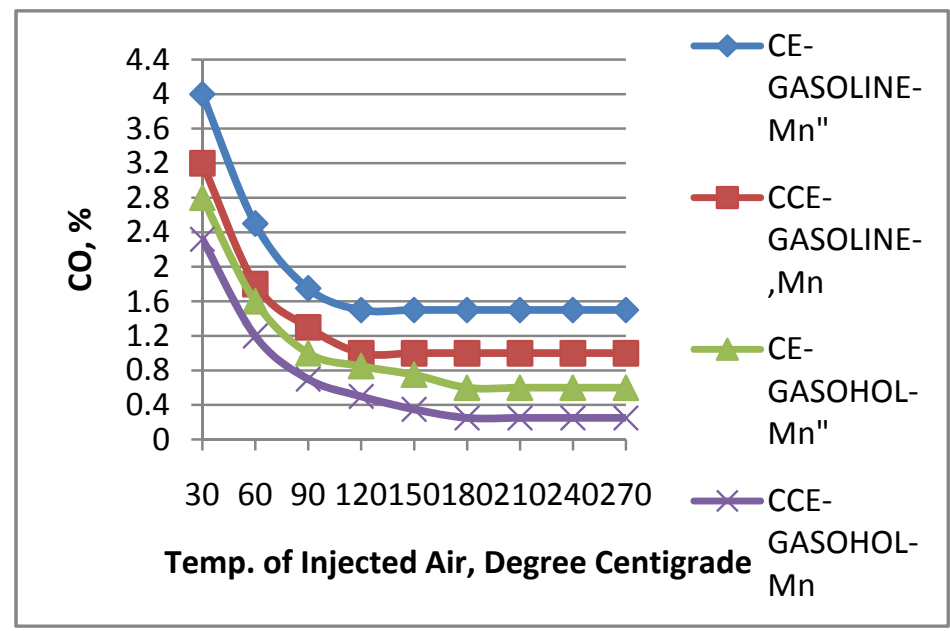

Figure 6(b). The variation of $\mathrm{CO}$ emissions with different test fuels with different configurations of peak load of the engine with temperature of injected air with manganese ore with void ratio of 0.7 as catalyst

Figure 6. The variation of $\mathrm{CO}$ emissions with different test fuels with different configurations of peak load of the engine with temperature of injected air with different catalysts with void ratio of 0.7 as catalyst 


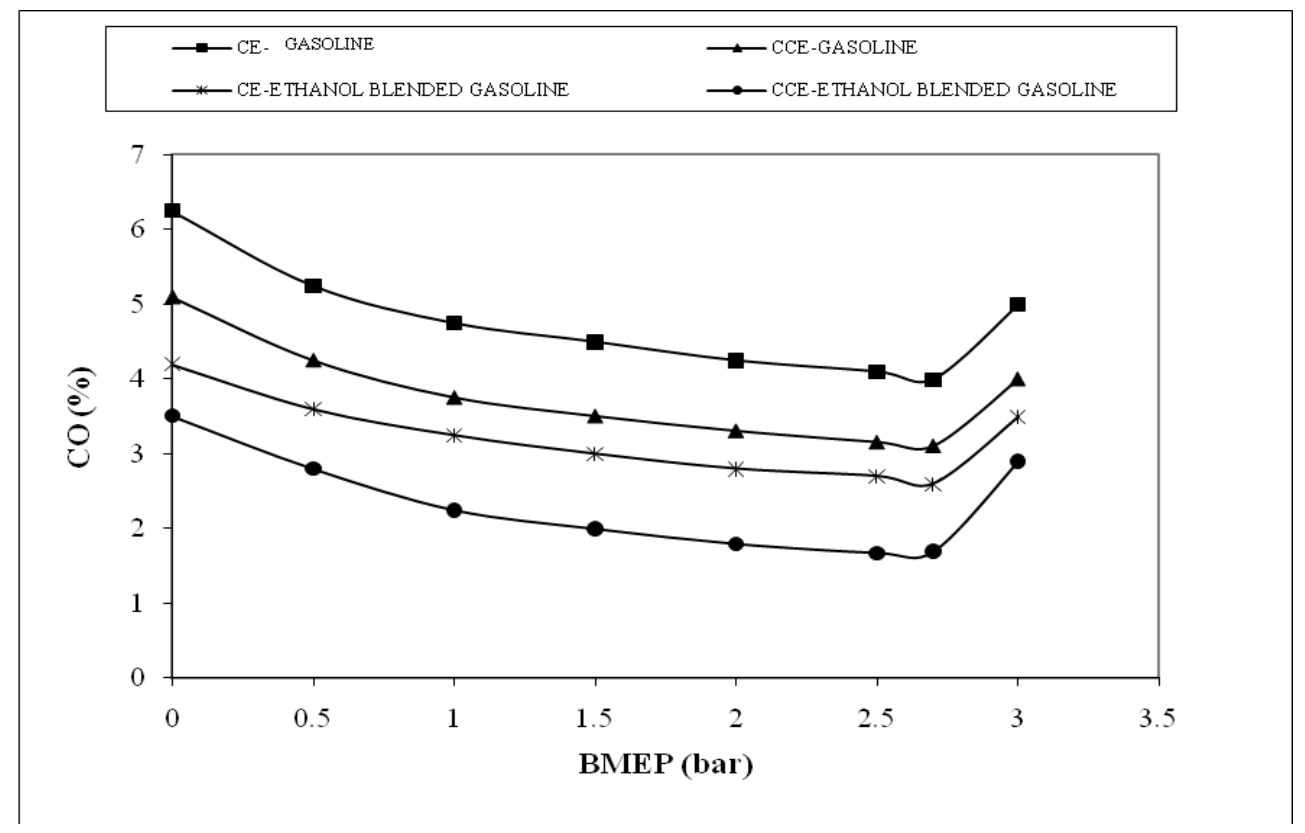

Figure 7. Variation of Carbon monoxide emissions with BMEP in different versions of the engine with pure gasoline and gasohol at a compression ratio of 7.5:1 and speed of $3000 \mathrm{rpm}$

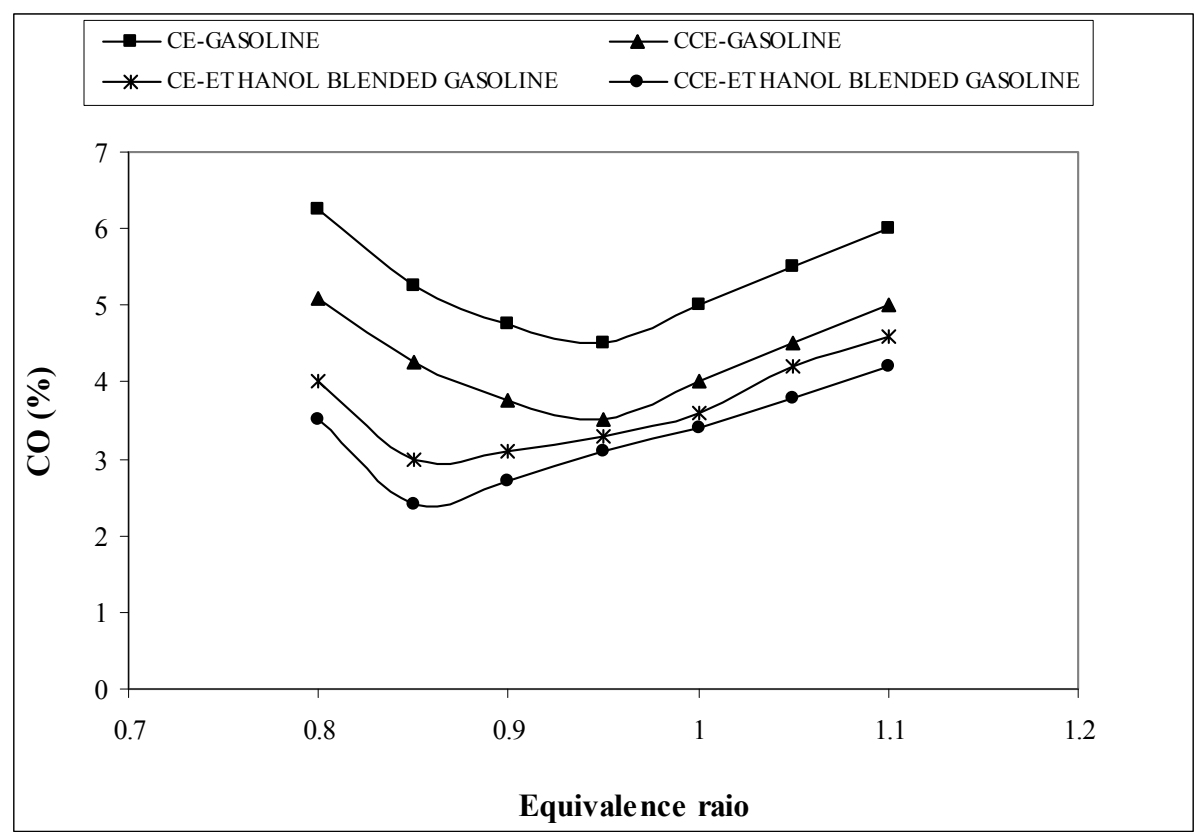

Figure 8. Variation of $\mathrm{CO}$ emissions with Equivalence ratio in both versions of the engine with different test fuels with a compression ratio of 7.5:1 at a speed of $3000 \mathrm{rpm}$ 


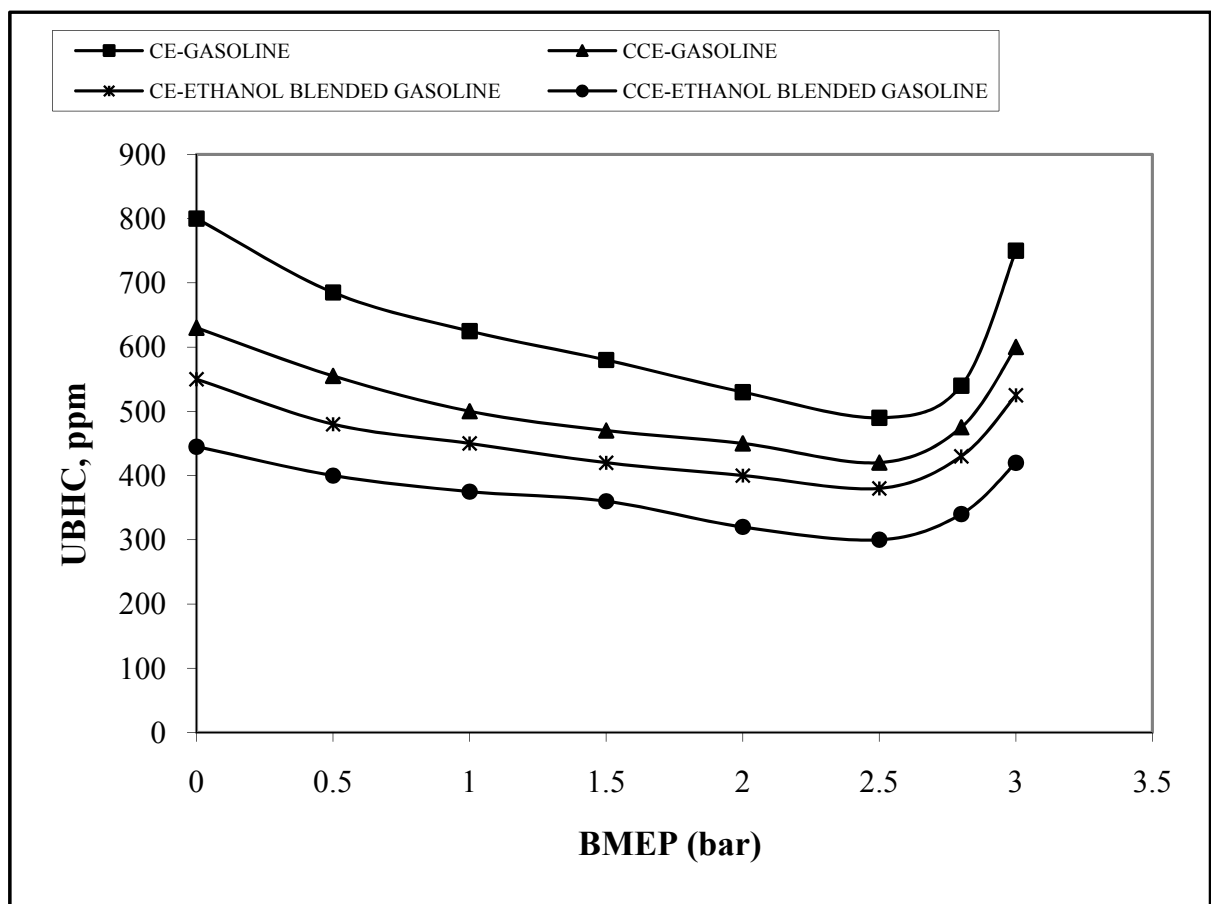

Figure 9. Variation of Un-burnt hydro carbon emissions (UBHC) with BMEP in different versions of the engine with pure gasoline and gasohol at a compression ratio of 7.5:1 and speed of $3000 \mathrm{rpm}$

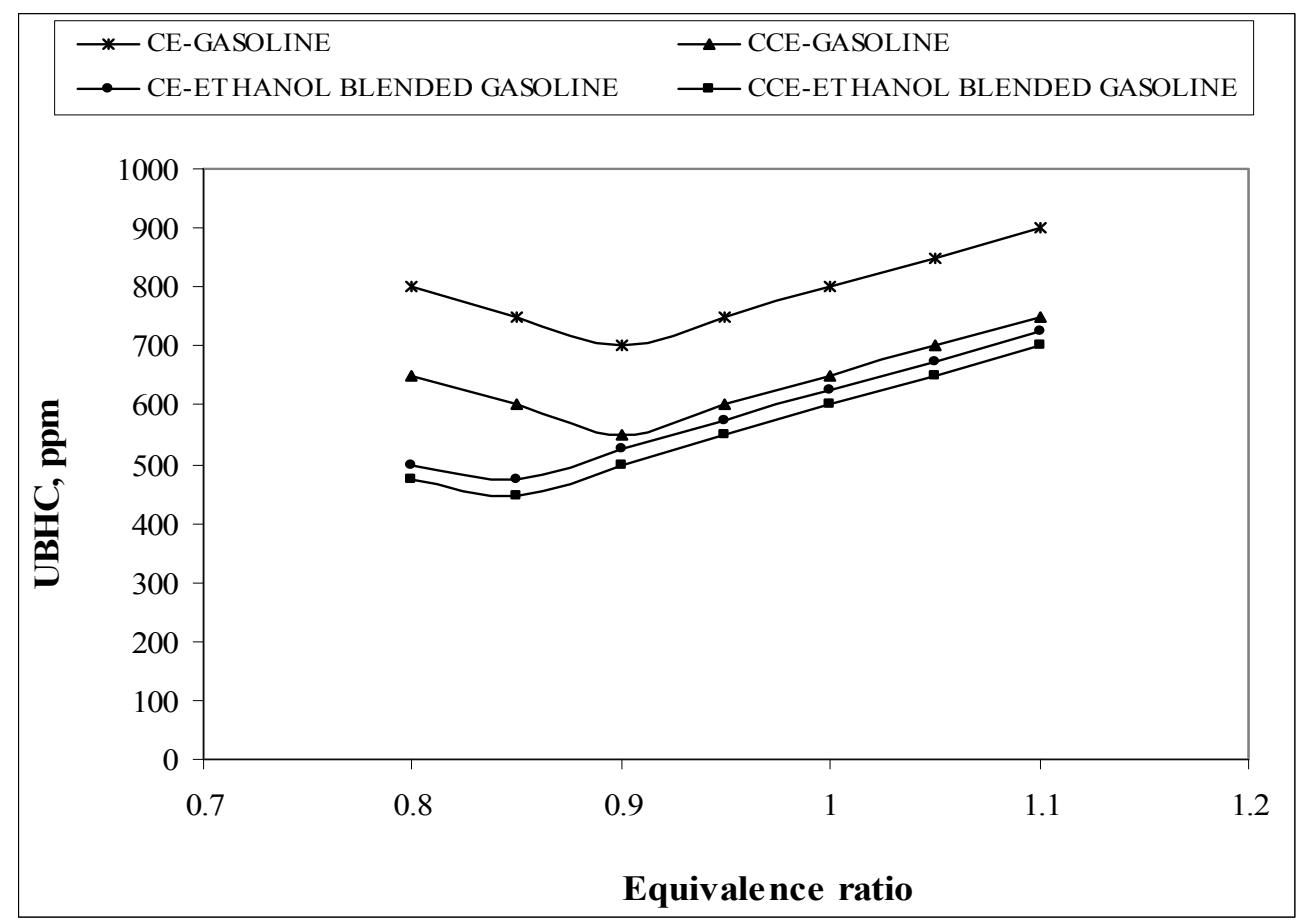

Figure 10. Variation of UBHC emissions with Equivalence ratio in both versions of the engine with different test fuels with a compression ratio of 7.5:1 at a speed of $3000 \mathrm{rpm}$ 